\title{
Institutionalizing Local Government as an Instrument of Democratic Consolidation: The Cases of Bulgaria and Paraguay
}

Polya Katsamunska, Allan Rosenbaum

\begin{abstract}
Multi-level governance is widely used throughout the world, especially in more economically developed countries. In part, this is due to the presumed benefits of decentralization in terms of public-service delivery, and in part, it is due to a desire to disperse political power and governmental authority. Thus, 25 years ago, when major governmental reform initiatives were begun in many countries around the world, especially in Central and Eastern Europe and Latin America, much attention was devoted to establishing and/or strengthening local governments. This was the case in Bulgaria and Paraguay, two countries from different parts of the world, but similar in size, economic development and a history of highly centralized and authoritarian regimes. The purpose of this paper is to examine and better understand the processes of decentralization as they took place in those two countries and those factors which facilitated and/or hindered efforts to initiate effective local government.
\end{abstract}

The 1980s and early 1990s were times of very significant governmental and economic change for both Central and Eastern Europe and Latin America. In Central and Eastern Europe, authoritarian, highly centralized, Communist governments, which had come to power in the aftermath of World War II, collapsed. They did so in large part as a result of a combination of their economic failings and the emergence of popular discontent, resulting in increasingly significant demonstrations in opposition to the prevailing regimes. In Latin America, equally authoritarian and centralized governments, which had frequently come to power through military coups in the 1950s and 1960s, also collapsed, as a result of both their economic and their political failings.

In both regions, as part of the process of seeking to institutionalize democratic governance, attention was devoted to establishing effectively functioning, demo- 
cratically elected local governments. These efforts were based on the presumption that local democracy was an important foundation for the building of a country's democratic institutions. In this paper, we shall examine the processes involved and the structures created in the efforts to establish effective, democratic local governance in Bulgaria and Paraguay - with particular attention paid to the role that these initiatives played in the institutionalization of democracy in each country. While on different continents, these two countries are quite similar in several ways - including size, population and the continuing impact of traditional culture on contemporary experience. Both also have economies with a strong agrarian focus and capital cities that are significantly larger and more highly developed economically than other cities found in the country. As a consequence, those cities have been historically dominant places where much of the political power of the country has been exercised.

In the remainder of this paper, the experiences of the two countries in seeking to build and institutionalize systems of democratic local governance as part of the broader processes of democratic institution-building will be examined. Our purpose is to gain a better understanding of what factors contribute both to the successful initiation of local governance and to its role in the promotion of effective democratic consolidation. To do so, the initial efforts to create democratic local governance in each country will be reviewed, and an effort will be made to better understand those factors which encouraged and those which impeded these processes. We will conclude with an assessment of the role that these local institutions played in the countries' efforts at democratic consolidation.

\section{The historic and political context}

BULGARIA: Intensive reforms aimed at establishing a democratic society and a market economy were initiated in the country in the early 1990s. The general structure of government powers was set with the adoption of the new constitution of 1991. The provisions for the establishment of local self-government in the 1991 constitution was very important in encouraging the decentralization of what previously had been highly centralized state authority. While not so during Communist times, in pre-Communist Bulgaria, local self-government had had some history as an established area of emerging democratic practice. Its origins can be traced back to the period of Turkish domination of Bulgaria. Of particular note, the first Bulgarian government actions upon liberation from the Turkish Empire, prior even to the adoption of the Turnovo Constitution in 1879, were establishing and regulating local self-government.

Historically, in the European context, there have been three main systems of local self-government - English, French and German. After its liberation in 1878, Bulgaria borrowed from the French system of local self-government. The Turnovo 
Constitution established a three-level local territorial organization - municipality, district and county. While these three forms of local government would continue, over the next 110 years, various administrative and territorial reforms would impact the structure of the local administration in terms of range and competence.

The radical political changes of November 1989 and the adoption of the 1991 Constitution both confirmed the democratic changes in the country and formulated the principles of local self-government in the Constitution's chapter VII. The constitutional framework of a two-level division of the country - regions and municipalities - represented the basis for the development of administrative and territorial reform in Bulgaria. ${ }^{1}$ The aims of the reform, as noted by Prof. Nora Ananieva (undated manuscript), have been

- the restructuring and development of the territorial, functional and institutional organization of local self-government, as well as the development of more effective relations and interactions with the institutions and the bodies of central authorities;

- the implementation and development of democratic procedures and mechanisms regarding the organization and functioning of local self-government;

- the integration of the local and regional structures of the country with analogous European structures.

The development of local self-government in Bulgaria also aimed at the institutionalization of the principles specified in the European Charter on Local Self-Government. After its ratification by the Bulgarian parliament, the European Charter on Local Self-Government acquired the force of a law and became an integral part of national legislation in compliance with the Constitution. By explicit constitutional provision, self-governing entities are free to associate and to unite their efforts in the solution of common matters. This has made it possible for various regional associations of local government to be formed, as well as for the creation of the National Association of Municipalities. ${ }^{2}$ The National Association was established in 1996 by 1/3 of all Bulgarian municipalities. In 1999, all 264 municipalities became members, which made the National Association of $\mathrm{Mu}$ nicipalities in Bulgaria a legitimate representative of local government and a force to represent and defend its interests. As a consequence, on both the national and

1 The specification of the constitutional principles of local self-government was the product of intensive legislative initiatives. The constitutional principles were further elaborated upon in a number of legal acts including the: Local Self-government and Local Administration Act; Administrative and Territorial Structure of Republic of Bulgaria Act; Municipality Property Act; the Law on Local Elections, the Law on Local Taxes and Charges; etc. Some of these, and a number of other laws, directly or indirectly regulating local self-government and local administration, have undergone a series of amendments.

2 National Association of the Municipalities in the Republic of Bulgaria Database. Available at www.namrb.org. 
regional levels, important relations between the Bulgarian associations, and their individual member municipalities, and the local governments of other European countries have developed.

The Law on Local Self-Government and Local Administration, adopted in 1995, specified the normative grounds of the basic administrative territorial units: the regions and the municipalities. The region is defined in the Administrative and Territorial Structure Act by its territory, population, borders, name and administrative center. Regions in Bulgaria have a triple function: to conduct regional policies; to execute the power of the state on the local level; and to provide for a balance between national and local interests. Each region is governed by a regional governor, who is supported in his or her activity by a regional administration. The regional governor is appointed by the Council of Ministers and is responsible for ensuring the implementation of the state's policy; the safeguarding of national interests, law and public order; and exercising administrative control.

In Bulgaria, in the middle of the 1990s, there were 9 regions and 255 municipalities. At present, Bulgaria has 28 regional territorial units and 264 municipalities. Each region consists of one or more municipalities. The 28 regions essentially are de-concentrated administrative units of the central government, which coordinate national and local interests. For the most part, the regional governor has served as a local representative of the national government. Taken together, 27 of the regional governors employ less than 1,000 staff members. The one exception is the capital city, Sofia, which by statute has the authority of a region.

According to the Constitution, the municipality - a legal entity - is the only tier of autonomous subnational government in the country. The "mayoralty local district" is the smallest territory of local self-government, and it operates within the territory of the municipality. They are the internal administrative structures of the municipality and in all cases are settlements with a population of more than 250 inhabitants. They are created to perform the functions and competences vested in them by law or by the force of the decisions of the municipal council.

PARAGUAY: On a continent where centralized government long has been the norm, Paraguay stands out for its high degree and long history of extreme centralization. Historically, the country's political and economic life has been focused upon Asunción, the seat of the National Government. A comparatively homogenous and geographically centralized population, combined with a general lack of cultural regionalism, further contributed to the centralist tendencies. Even in Paraguay's rural areas, with its large agrarian peasantry, a small land-owning elite was historically dominant and has become even more so over the past century. The result has been that, since the country's independence in 1811, with but a few brief exceptions, it has been ruled by an almost unbroken string of dictatorial, highly centralized regimes which were led by individuals much more concerned with conserving, or gaining, wealth than providing services or opportunity to the nation's citizens. 
Notwithstanding the division of power established in various constitutions - which have mandated separate executive, legislative and judicial branches - authoritarian leadership in the executive branch or the military, based in Asunción, has virtually always determined the country's political and economic fate. During much of the four decades prior to the February 1989 coup against General Alfredo Stroessner (led by his son-in-law, who, at the time, was the army chief), this authoritarianism was reinforced by a close alliance between the military, the long-ruling Colorado Party and the country's very small landed and entrepreneurial elite. This concentration of power prevented the development of a normal equilibrium between either branches or levels of government in Paraguay.

The country's initial municipal elections of May 1991 were of extraordinary importance in the process of democratic development in Paraguay for several reasons. Not only was this the first time in the country's history that local mayors (lntendentes) were elected by the people (as part of a comprehensive municipal election process), but the mayoral election in Asunción also witnessed the ending of half a century of single-party domination of all aspects of government and political power by Paraguay's Colorado Party (or Asociación Nacional Republicana, ANR). The winning mayoral candidate, Carlos Filizola, who had been jailed and tortured in earlier years as a student leader for his opposition to the Stroessner regime, ran on a platform of building citizen engagement in Asunción's local government.

Of the country's remaining 216 municipalities, another 43 elected mayoral candidates of the long, politically suppressed (opposition) Liberal Party or PLRA (Spanish acronym for Authentic Liberal-Radical Party) and another five elected political independents. The Colorado Party did, however, win 75 percent of the country's mayorships, the majority of which were in rural locations. Nevertheless, the results did encourage Paraguayans concerned with building democratic institutions to increasingly focus upon issues of dispersing political power by decentralizing national authority and strengthening local government (at least in part through encouraging citizen participation) as key areas of reform. Another unprecedented aspect of the May 1991 municipal elections was the gain made by women in the electoral process. ${ }^{3}$

3 Even in the context of a Latin American tradition of male domination of electoral offices, Paraguay is an extreme case. Because of that the Colorados incorporated into their party statute a 20-percent-minimum participation quota for women. The movement, Asunción Para Todos, which was victorious in Asunción, established in its statutes that no one gender could control more than 60 percent of the senior offices or be represented in more than 60 percent of the electoral slates. 


\section{The structures and bodies of local government in Bulgaria and Paraguay}

BULGARIA: Local self-government in Bulgaria embodies two main forms of democracy - representational and direct. At present, representational democracy prevails, and the participation of the citizens occurs mainly through their right to vote and elect their bodies of local self-government. Direct democracy, although envisaged in the Constitution as involving referenda and general meetings of the population, rarely occurs. The principal bodies of local government - the Municipal Council and the Mayor - are elected directly by the local population for a 4-year mandate with the purpose to make and implement governmental decisions. The election procedure is determined by the Local Elections Act (1995).

The municipal council is the main body of self-government in the municipality, and it is comprised of municipal councilors elected on the basis of proportional representation. It determines the policies for the development of the municipality. In order to do so, the municipal council creates continuing and temporary commissions and selects their members. The typical municipal council establishes commissions on education, health protection, finances, culture, sport, building and economic development, etc. The law commission is especially important because it verifies the correspondence between the municipal-council decisions and state legislation. Temporary commissions are set up in order to address specific problems which need to be solved. Experts and consultants can be involved in the work of the commissions. The municipal council sessions are public, and they are advertised in the local media so that citizens can participate.

The Law on Local Self-government and Local Administration regulates and empowers municipalities to make decisions on a variety of issues connected with the everyday life of the citizens. The municipal council adopts the municipal budget, exercises oversight of its implementation, approves financial reports, defines the rates of local taxes and charges (within the limits established by national legislation), makes decisions to acquire or sell municipal property and to create, transform and/or terminate the activities of municipal companies, etc. Effective decisions regarding the various areas of competences of local self-government depend to a great extent on the interaction of the municipal council and the mayor in that while the municipal council adopts policies, the mayor is responsible for the implementation of its decisions.

The national Constitution defines the "mayor" as the head of the executive power of the municipality. The mayor performs various executive functions and manages the municipal administration. The mayor oversees the municipal budget and the implementation of the municipal council's decisions. The elections for mayor take place in two rounds, based on the majority system. A candidate who gains the absolute majority of votes in the first round becomes mayor. A second round 
is organized a week after the first round if none of the candidates has received the majority of all votes cast. Only the first two candidates may participate in the runoff election, and the candidate who gains the most votes becomes mayor. There is a two-year lag between central-government and local elections in Bulgaria. In the last local elections, held at the end of 2011, respectively 264 mayors and municipal councils (including 5,234 municipal councilors) were elected. Men were elected to the majority of the municipal-council seats.

The municipal council and the mayor are placed in co-subordination, but their competences are differentiated. Particular emphasis is given to the mayor as regards the preservation of public order and the defense of citizens in cases of natural disasters and accidents. In such situations, the mayor has the capacity to issue written orders which are compulsory for the police authorities. Relations between the two bodies of local self-government within a given municipality are frequently charged with conflicts. This is compounded by the fact that often a mayor is placed in a situation where they must work with a majority from another political party or coalition. Dialogue and consent are used to manage the conflicts between them. However, often this approach does not work effectively and thus blocks, and often discredits, the work of local self-government bodies. The ability of municipal governments to effectively address local problems is further hindered by the fact that they remain relatively small with a total of only 30,000 employees for all 264 municipal governments, and a large number of them are to be found in Sofia. In contrast, the national government employs, depending upon what source one draws upon, between 110,000 and 130,000 individuals.

Municipal Revenues: The main instrument for the management of the activities fulfilled by the municipality on its territory is the municipal budget. The municipality has the right to own property and adopts an independent municipal budget which is to be used in the interests of the local population. The separation of the national government and local governments, and the initiation of major municipal activities, occurred with the beginning of the financial decentralization process in 2003. Activities such as education, social-welfare programs, cultural and health services, which are delegated by the state on the basis of financial standards, continue to be financed from the national budget.

Municipal funds come from three main sources: subsidies from the national budget (state transfers), own resources and attracted resources. The approved annual state budget by the Parliament includes mandatory fund allocations for the municipalities for the adoption of their budgets. State transfers are distributed according to objective criteria, such as territory, population, etc. Every municipality is allocated resources to develop an independent budget, and the permanent financial resources available to them are specified by the municipal law. The collection of own income in the municipal budget is carried out by the municipal administration. In 
general, the more developed municipalities rely less on state support and thus are more independent from the state in determining priorities and policy.

A special Law on Municipal Budgets was adopted in 1998, and according to it, the municipal budget is developed and approved every year by the Municipal Council. The budget's implementation is organized by the mayor of the municipality and assisted by elected and appointed heads of districts and villages and the head of the budget unit. The municipal budget is public and controlled by citizens through the Municipal Council, the Chamber of Accounts and State Finance Control. Because local taxes and charges are strictly specified and the income from public services is not sufficient to meet demands, municipal resources are highly dependent upon state transfers. However, since the transitional period, subsidies for municipalities have been decreased gradually and continuously, while the obligations of municipalities have expanded. Thus, in recent years, municipal budget deficits have increased considerably.

The sources of municipal revenues are specified in the law on Local Taxes and Charges. Local taxes are levied on real estate, inheritance, transportation vehicles, purchased property, donations, etc., while local charges involve charges for administrative and public services, as specified by law. The rate of taxes is specified by the law, while the rate of various charges is either specified within certain limits or set by the municipal council. Revenues from taxes are a very important factor for the development of municipalities. However, municipalities may also attract resources from loans, municipal bonds and economic operations which are allowed to be done by the municipalities.

Own municipal revenues are dominated by several budget items. In terms of taxes, these are the real-estate tax, the vehicle tax and the tax on acquisition of property. Non-tax revenues are dominated by the waste-collection charge. It is noteworthy that despite social tension related to municipal waste-collection charges, in recent years, revenue from the so-called "garbage charge" has remained relatively stable. ${ }^{4}$ At the same time, the revenues from property taxes have increased. Only the revenues from the tax on acquisition of property are still depressed, which is to be expected, given the slump in the real-estate market. There is one other point to be noted. There are serious differences among municipalities with respect to fiscal independence and dependence on state transfers. In Sofia, for instance, own revenues exceed transfers, reaching $60 \%$ of the budget. Varna is also close to that with $60 \%$, while in Plovdiv and Bourgas half of municipal revenue is from own revenues, and the other half is from transfers.

4 During 2013 and 2014, increased garbage and electricity charges sparked widespread political protests. 


\section{Table 1}

Main sources of municipalities' own revenue in milions of BGN

$\begin{array}{lrrrrr} & 2008 & 2009 & 2010 & 2011 & 2012 \\ \text { Municipal own revenues, including: } & 1781 & 1517 & 1517 & 1663 & 1688 \\ \text { real estate taxes } & 137 & 172 & 192 & 227 & 240 \\ \text { vehicle taxes } & 125 & 154 & 162 & 169 & 181 \\ \text { tax on property acquisition } & 363 & 191 & 170 & 189 & 189 \\ \text { waste collection charge } & 396 & 437 & 468 & 498 & 463\end{array}$

Source: Ministry of Finance, IME

In general, the years after 2007 were turbulent ones for municipal budgets and the country's fiscal policy. The revenue growth in 2007 and in 2008 was followed by a decline after the onset of the world-wide economic crisis in 2009. The crisis revealed the lack of adequate tools for the implementation of an appropriate fiscal policy at the local level. As Graph 1 indicates, in 2008, the annual tax revenues of municipalities exceeded municipal debt, but then the picture changed considerably: within just one year, municipal debt got seriously ahead of municipal tax revenues. During the "hard years", municipalities started accumulating larger deficits; in 2009 and 2010 deficit exceeded municipalities' own revenues by $15 \%$ : a total of over BGN 500 million in deficit for the two years for all municipalities. There were extreme cases of freezing accounts and temporary closure of municipal services. At the end of 2012, the amount of debts had already doubled, reaching nearly BGN 1 billion, with external debt slightly larger than the domestic debt.

\section{Graph 1}

Municipal debt (mln BGN)

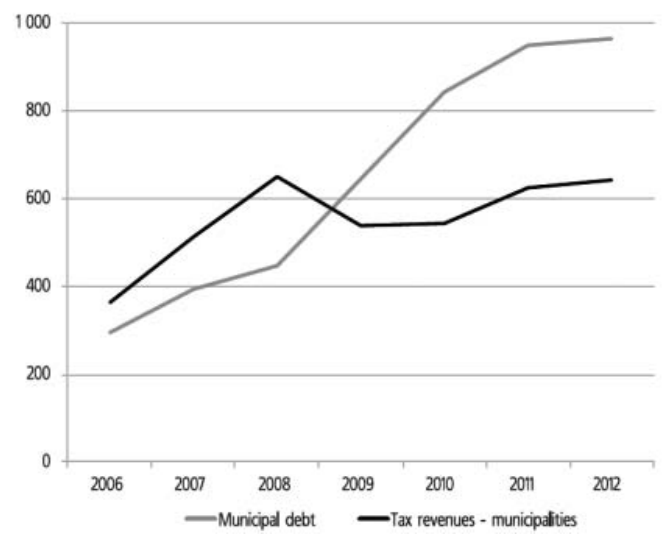

Source: Ministry of Finance, IME 
Almost half of all municipal debt is that of the Sofia Municipality. Currently, the amount of municipal debt is about $60 \%$ of the municipalities' so-called "own revenues". At present, tax revenues no longer cover municipal debt. However, the distribution of municipal debt is not even. There are quite a few municipalities with no accumulated debt, while other municipalities have accumulated debt that exceeds their own revenues (from taxes and fees) for the year.

PARAGUAY: The country is administratively divided into 17 Departments and 217 municipalities that vary in size, population and importance. The Constitution of 1992 introduced the figure of Governor as the executive power of the Departments within a still "unitarian" country. Consequently, just as the municipal elections of May 1991 marked a major step in the twin processes of democratization and government decentralization, so, too, does the establishment of the National Constitution of 1992 because it instituted the basis for decentralization in Paraguay.

The issue of decentralization became an important one during the Constitutional Assembly in Paraguay, as it has over the years in many Latin American countries. In Paraguay, as elsewhere, this was, at least in part, due to the efforts of rural elites to create institutions that would be more susceptible to their control in the newly democratic Paraguay. However, the past failures, both in Paraguay and throughout Latin America, of highly centralized governments in delivering adequate basic services and in representing the needs of the people was also an important factor. Moreover, centralized systems had come to be seen in many countries as instruments of social control and repression. Consequently, with the return of democracy to the continent in the 1980s, decentralization and the strengthening (or in some cases the creation) of local government became major concerns in much of Latin America.

In Paraguay, prior to the 1992 Constitution, there was no constitutional basis, and certainly no political will or inclination, for the decentralization of government and political power outside of Asunción. The National Government of Paraguay had, since the beginning of the $20^{\text {th }}$ century, organized various designated regional and local administrative units. However, they possessed neither any authority nor any autonomy from the National Government and had no independent capacity to act - either inherent or delegated. For the most part, they were of no consequence to anyone except for the person appointed as the regional representative of the $\mathrm{Na}$ tional Government, who frequently used the position for personal gain. Not surprisingly, the level of national commitment to the decentralization of governance (and political power), as manifested in the provisions of the 1992 Constitution, reflected considerable ambiguity, as illustrated in the Constitution's first article, where Paraguay is characterized as both a "unitarian" and a "decentralized" state.

The 1992 Constitution established that the 17 Departments would be presided over by a Governor and a Departmental Council (Junta Departamental), elected directly by popular vote for five-year terms. Members of the Departmental Council, 
but not Governors, could be reelected. The Constitution (and later, the Departmental Administrative Law) establishes that Governors, while elected directly by the people, are expected to represent the President of the Nation in the Department. This provision has from time to time become a source of difficulty when there is a conflict of interest between the residents of a Department and the concerns of the President of Paraguay. Because they are directly elected, Governors will from time to time take positions in opposition to the national government.

The Constitution established that the government of municipalities would be under the direction of a Mayor and a Municipal Council, who are elected directly by legally qualified persons, for five-year terms. Mayors, like Governors, cannot be reelected. The Municipal Law establishes that the Municipality of Asunción's "junta" or council will have 24 members. In other cities, the number of members varies from nine to twelve, based upon population and size of annual budget.

Another important constitutional action which has encouraged the decentralization of political power and government activity involved the structuring of political representation in Paraguay's national legislative body. Pre-1989, the members of both houses of Congress were elected from closed national party lists with no consideration given to geographical distribution. The 1992 Constitution provided for the election of members to the 80-person House of Representatives (La Cámara de Diputados) by Department, with a variation in the sizes of the delegations in accordance to the number of voters in the Department (with Asunción as a special electoral district). ${ }^{5}$

Departmental Governance: Paraguay's 17 Departments vary greatly in population size and density. The Department of Central, which surrounds the special capital district of Asunción, has the largest population, about 1,000,000, and a density of about 400 people per square kilometer. In contrast, the Department of Alto Paraguay, though much larger in land area, has a total population of approximately 21,000 and a density of less than four people per square kilometer. This variation in size is reflected in the size of the Departmental Councils and congressional delegations. Departmental congressional delegations in the Chamber of Deputies range in size from seventeen for Central and thirteen for the special district of Asunción (population 550,000) to one each for the four smallest Departments.

Departmental Governments are still very modest operations with relatively small staffs. The combined total budgets for all 17 departmental governments in 2012 were a little over 100 million dollars. This funding came entirely through transfers from the national government which were very tightly controlled and closely overseen by the Ministry of Finance. The typical Governor appoints a cabinet with Secretaries (and one or two administrative staff) in the areas of Education,

5 The 1992 Constitution provides that the Chamber of Senators will have a minimum of forty-five members and thirty "replacements", directly elected by the people in one national electoral district. 
Public Works, Transportation, General/Cabinet and Agriculture. Additionally, the Governor usually has a General Secretary and a Director of Administration. Thus, a typical Governor oversees twenty to thirty employees. In the case of the two largest departmental governments, Central and Paraguarí, the total departmental staff is likely to be about 60 employees. The Junta Departamental, or Council, for a Department typically is served by one secretary.

Municipal Governance: Paraguayan municipalities are regulated by Articles 166 to 171 of the National Constitution, which defines municipalities as "organs of local government, with legal personality which have political, administrative, and normative autonomy within their jurisdiction, as well as absolute sovereignty in the collection and investment of resources." Article 168 of the National Constitution stipulates that the functions and attributions of the municipalities will include:

jurisdictional management, particularly in the areas of urban planning, the environment, supplies, education, culture, sports, tourism, sanitary and health services, credit institutions, and police and inspection agencies; the administration and arrangement of its assets; the design of its budget for income and expenses; participation in national revenues; the issuance of ordinances, regulations, and resolutions; access to international and national private and public credit; the regulation and control of transit, including public transportation and other matters related to the circulation of vehicles; and, other functions established by this Constitution and the law.

While the Constitution's listing of areas of responsibility seems at first glance to suggest that municipalities have broad authority and power, the reality for all but a dozen or so of the country's local governments is quite different. Most municipalities have very few employees (under two dozen) and so few resources that only a minority of the country's municipalities would have access to any significant form of computing or word-processing equipment. Basic statistics on government expenditures and public employment dramatically illustrate the high degree of centralization that still typifies the Paraguayan public sector. In 2012, there were about 220,000 National Government public employees (including the military and national police force). In total, the 217 municipalities employ no more than 20,000 public employees (five or six thousand of whom work for the Municipality of Asunción). The 17 Departmental Governments together employ no more than a few thousand people.

Paraguay's long tradition of centralized government has created a system in which almost all important public services are delivered and controlled by highly centralized National Government ministries. The regulation of public interurban transportation, primarily privately provided, is controlled by the Ministry of Public 
Works and Communication, which is also in charge of road construction for the country. Street lighting is the responsibility of the National Electricity Administration (ANDE). Drinking water, storm drainage and sewers are in the hands of either CORPOSANA or SENASA, both National Government entities. The construction of community housing is carried out by two national government agencies. The development of local employment plans and programs is a function of a unit of the Ministry of Justice and Labor. Public health services are almost entirely provided by the Ministry of Public Health and Social Welfare, and the Ministry of Education and Culture is in charge of public education from the elementary through the university level.

Thus, the real functions of almost all municipalities are much more modest than they would appear based on a review of the Constitution and municipal law. In effect, given the centralism which still continues to characterize Paraguay, the primary municipal functions of the dozen or so larger Paraguayan municipalities include:

1) limited physical planning of the municipality and some street paving;

2) sanitation and garbage collection services (often very limited);

3) regulation of markets, slaughterhouses and cemeteries and the control of animals and food; (again, often very limited);

4) the regulation and control of local transportation, the circulation of vehicles; the provision of public bus terminals and the management of the municipal trafficpolice force;

5) the regulation of public markets, pawnshops and the municipal bath.

In fact, however, even this is misleading in terms of the great majority of Paraguay's municipal governments. Physical and urban planning is practically non-existent in most municipalities, and one study of municipalities found that most did not even install a system of traffic signs. Most small municipalities had no capacity for garbage collection, nor any ability to implement even minimal health and safety regulatory activities.

Historically, citizen participation in any overtly political sense had, until 1989, been strongly discouraged in Paraguay. Many Paraguayans were forced to leave the country for political exile as a result of their involvement in political activity. Others who stayed and opposed the government were beaten, tortured, imprisoned and, upon occasion, killed by the military or the police. Since the overthrow of General Stroessner in 1989, however, the country has witnessed a gradual evolution of increasing citizen involvement in political and governmental processes. As a result, political demonstrations are now a regular phenomenon, especially in the national capital of Asunción. Nevertheless, many forms of citizen participation which are relatively commonplace and taken for granted in established democratic systems 
have simply never had the opportunity to emerge and flourish in Paraguay. However, during the latter half of the twentieth century, the country witnessed the emergence of a strong tradition of creating informal local or neighborhood committees for the purpose of constructing public works (roads, schools and bridges).

Since the demise of the Stroessner regime, however, Asunción has been the site of substantial developments in citizen participation. There now are approximately two hundred non-governmental organizations (NGOs) operating in and around Asunción - many of which are quite active. While many of them are engaged primarily in research and technical-assistance activities, they often encourage citizen involvement both through their internal activities and their external programmatic activities, as well. In addition, several of these organizations are heavily involved in the promotion and development of citizen participation and have either carried out or encouraged the carrying out of a number of projects designed to develop and strengthen aspects of community life through citizen engagement.

Municipal Revenues: Historically, municipalities in Paraguay have had only a very limited capacity to impose and collect taxes or to raise other forms of revenue. Moreover, there is also no tradition of the National Government engaging in any dependable and sustained form of revenue-sharing. Indeed, Paraguayan municipal revenue laws are for the most part administered in a very restrictive manner, and their administration is directly and closely monitored by national agencies. Traditionally, virtually all revenues collected at the municipal level are remitted directly to the National Government.

While municipalities in Paraguay have the authority to collect property tax, because property values in Paraguay historically have been vastly under-assessed (or, in some instances, not assessed at all) and because municipalities are very restricted in their ability to increase property assessments, this has not been very beneficial. The national government's Finance Ministry (Ministerio de Hacienda) sets the values to be charged for property tax, which is composed of a tax on the land and a tax on any building on it. Most municipalities have three categories of property values, depending on whether properties are located upon paved streets, stone streets or dirt streets. Property-value increases are limited to a maximum of 15 percent per year plus inflation. Therefore, property values, which have been and still are greatly understated, rarely reach anything near real values.

Municipalities do have access to the receipts from a variety of tariffs and fees that they may collect for local services provided under municipal ordinances. For the most part, however, the rates that they may set again are very limited and closely regulated by the National Government. The financial situation of Paraguay, and its municipalities, was improved, however, with the enactment of a new municipal law passed by the Paraguayan Congress in 2010 after some 15 years of discussion and debate. The law provides that municipalities should receive a small portion of the country's value-added tax, as well as portions of various gambling taxes. In addition, 
it provides for municipalities to receive specified portions of national development funds which derive from fees received from two very large hydroelectric projects which Paraguay shares - in one case with Brazil and in the other with Argentina. However, the degree to which the provisions of the law are fully implemented is unclear.

\section{Conclusions}

Both Bulgaria and Paraguay have been countries engaged in a long and complex process of attempting to institutionalize and consolidate democratic government. In both cases, the process has been a difficult one with some steps forward and some backward. Particularly vexing has been the problem of corruption, which has plagued each country throughout their recent histories as fragile democracies and, certainly, from long before that as well. Both countries have also been the scene of considerable political protest activity, especially aimed at their national governments, in whom many citizens lack trust.

One important vehicle which reformers have sought to utilize in their attempts to institutionalize democratic government has been to focus upon the strengthening of local government. This has been based upon the assumption that the dispersal of political power among different levels of government, and across numerous municipalities, would lessen the inherent historically centralist tendencies of both countries. Towards this end, in the early days of democracy in both countries, considerable emphasis was put upon efforts to build and strengthen local-government institutions in each place.

The process of gradual political, administrative and financial decentralization in Bulgaria started in 1991 with the adoption of the new Constitution of the Republic of Bulgaria, which legally establishes and protects local self-government principles. The process of developing local self-government in Bulgaria was in part facilitated by the country's history which, prior to the emergence of the communist regime, included some experience with decentralized local government. The scope of the current bodies of local self-government include the authority to act upon a wide variety of issues concerning municipal property, municipal enterprises, municipal finances, taxes and charges, municipal administration, education, health care, culture, sports, public utilities and services, social welfare, environment and development of natural resources, sports, leisure activities and tourism of municipal significance. On one hand, the wide scope of competencies possessed by local self-government is a positive. On the other hand, it often leads to conflictual situations between the mayor, the municipal council and the national government. The mayoralty has, however, over the years emerged, especially in Sofia, as an important political office and a stepping stone to national office, including the Prime Ministership. 
Paraguay has been in transition for the past twenty-five years and is likely to be so for some time into the future. It is moving away from an almost two-centurylong tradition of authoritarianism and a remarkably high level of centralization. Perhaps not surprisingly, over the course of the past 20 years, there has not been nearly as much consolidation of democratic processes within Paraguay as occurred in the first few years immediately following the fall of the Stroessner dictatorship. At the national level, elections for president and congress always have taken place as scheduled. However, the Colorado Party has, for the most part, returned to a relatively dominant role in the country's politics. Nevertheless, fractionalization within the Colorado party has from time to time opened up possibilities for the Liberal Party to make significant gains in the Congress, or, as occurred in 2008, a decidedly left-leaning coalition to win the presidency. ${ }^{6}$

At the subnational level, the past 20 years have produced a mixture of some moments of progress in terms of democratic development and some moments that have been less encouraging. In several instances, individuals elected to the newly created mayoralties have used those offices as stepping stones to develop political careers that have led them to various Departmental governors' offices and to the National Congress. The mayoralty of Asunción, the most prominent of the country's local-government offices, has gone from first being held by an independent to a member of the Liberal Party and, in more recent years, has returned to being held by members of the historically dominant Colorado Party, some of whom have shown a steadily decreasing enthusiasm for citizen engagement and political reform.

At present, there are still some forces to be found in different strata of Paraguayan society that are strongly committed both to democratization and to political and governmental decentralization. While there have been hopeful signs, and a number of important changes in political and governmental organization have occurred over the past three decades, it is by no means a foregone conclusion that these forces will succeed in building a secure, transparent and vibrant democracy. Nevertheless, one very important step in the twin processes of decentralization and democratization has been the emergence of subnational - Departmental and $\mathrm{Mu}-$ nicipal - governments within the still heavily centralized country.

6 The 2008 election brought to the presidency a seemingly very reform-minded Catholic Bishop, Ferdinand Lugo. However, in what is arguably the most significant of various challenges to democratic institution-building in the country's recent history, in 2012, Lugo was, over the course of two days, impeached and forced from office by the Congress nine months prior to the conclusion of his term. In part, the impeachment represented an effort by the country's political elite to undercut potentially left-leaning reform efforts. The impeachment was, however, in part facilitated by the reality that Lugo's administration had not been very effective. Numerous newspaper stories that he had fathered several children with various parishioners did not help his situation. The 2012 election did, however, go forward without any real complications in spite of widespread allegations that the multimillionaire businessman who won the election had made a good part of his fortune through illegal smuggling activities. 
The experience of the two countries in institutionalizing local government as an instrument of democratic state-building, while varying in some specifics, has been remarkably similar overall. In the early days of democratic transition, much attention was given to the building of institutions of local government because of a belief that they could serve as the foundation upon which democratic governance could be built. The result was initially a very positive one. However, not surprisingly, central-government resistance to the transfer of governmental and economic resources away from the national government and to the local governments quickly emerged. Thus, while the development of local government has continued to be a positive force in terms of democratic institutionalization, the progress in this regard has not nearly been as great as the early enthusiasm for these efforts might have suggested.

\section{References}

Ananieva, N. Undated Manuscript. Local Self-Government in the Republic of Bulgaria: from Constitutionally Proclaimed Principles to Effective Actions.

Ballard, Rachel and Allan Rosenbaum. 1999. "Reforming Municipal Budgeting and Finance Management in a South American City: A Case Study of Asunción, Paraguay." In E. H. Valsan (ed.). Democracy, Decentralization and Development Selected International Experiences. Copyright International Association of Schools and Institutes of Administration, Brussels, Belgium. Printed in Egypt at the American University in Cairo Press, 60-72.

Constitution of the Republic of Bulgaria, adopted № 12 July 1991.

Foundation for Local Government Reform Database. Available at www.flgr.bg.

National Association of the Municipalities in the Republic of Bulgaria Database. Available at www.namrb.org.

Rosenbaum, Allan. 2009. "Decentralization, Local Government and Democratic Institution Building" in Journal of Regional Studies and Development 18(1), 59-81.

Rosenbaum, Allan, Cristina Rodriguez Lagier, Karen Shaw, Víctor Jacinto Flecha, Todd Sorenson and Alejandro.

Rodríguez. 1995. PARAGUAY Decentralization, Subnational Government, Citizen Participation and the Process of Democratization: A Diagnostic Analysis For: Local Governance and Municipal Development.

Project Contract Number 598-0799-C-00-3325-00. Quito, Ecuador; United States Agency for International Development.

Stoilova, D. Undated Manuscript. Local Government Reforms in Bulgaria: Recent Developments and Key Challenges. 